\title{
Heavy Rainfall Simulation over Sinai Peninsula Using the Weather Research and Forecasting Model
}

\author{
Gamal El Afandi, ${ }^{1,2}$ Mostafa Morsy, ${ }^{2}$ and Fathy El Hussieny ${ }^{2}$ \\ ${ }^{1}$ Division of International Research and Development, College of Agriculture, Environment and Nutrition Sciences and \\ College of Engineering, Tuskegee University, Tuskegee, AL 36088, USA \\ ${ }^{2}$ Astronomy and Meteorology Department, Faculty of Science, Al Azhar University, Cairo 11884, Egypt
}

Correspondence should be addressed to Gamal El Afandi; gamalafandy@yahoo.com

Received 8 August 2012; Revised 18 November 2012; Accepted 11 December 2012

Academic Editor: Prodromos Zanis

Copyright (C) 2013 Gamal El Afandi et al. This is an open access article distributed under the Creative Commons Attribution License, which permits unrestricted use, distribution, and reproduction in any medium, provided the original work is properly cited.

\begin{abstract}
Heavy rainfall is one of major severe weather over Sinai Peninsula and causes many flash floods over the region. The good forecasting of rainfall is very much necessary for providing early warning before the flash flood events to avoid or minimize disasters. In the present study using the Weather Research and Forecasting (WRF) Model, heavy rainfall events that occurred over Sinai Peninsula and caused flash flood have been investigated. The flash flood that occurred on January 18, 2010, over different parts of Sinai Peninsula has been predicted and analyzed using the Advanced Weather Research and Forecast (WRF-ARW) Model. The predicted rainfall in four dimensions (space and time) has been calibrated with the measurements recorded at rain gauge stations. The results show that the WRF model was able to capture the heavy rainfall events over different regions of Sinai. It is also observed that WRF model was able to predict rainfall in a significant consistency with real measurements. In this study, several synoptic characteristics of the depressions that developed during the course of study have been investigated. Also, several dynamic characteristics during the evolution of the depressions were studied: relative vorticity, thermal advection, and geopotential height.
\end{abstract}

\section{Introduction}

Heavy rainfall is one of the major severe weather in Egypt particularly in arid and semiarid regions especially if it is steep and mountainous regions such as Sinai Peninsula and the Eastern desert of Egypt. Short duration of heavy rainfall over a relatively small drainage area can lead to devastating flash flood, consequently causing a number of fatalities and tremendous damages.

It can destabilize soils along mountain slopes, resulting in landslides and mudslides that cause severe damage to nearby villages.

Heavy rainfall is usually resulting from individual mesoscale storms or mesoscale convective systems embedded in synoptic-scale disturbances [1]. High-resolution observations and numerical modeling technique are required to better predict heavy rainfall events, where the forecasting of heavy rainfall is very important for many decision makers who are sensitive to the occurrence of precipitation. An accurate quantitative precipitation forecast can identify the potential for heavy precipitation and possible associated flash flooding, as well as provide information for hydrological interests.

Since heavy rainfall and flash flood can lead to severe damage and losses for both life and infrastructure, the need to warn people in advance is, thus, an important goal, but heavy rainfall and flash floods forecasting is considered a difficult task, particularly in arid and semiarid regions, since they take place in very short time interval. Hence, rainfall forecasting is very much necessary for providing an early warning before the flash flood events to avoid or minimize disasters.

An early warning system (EWS) for flash floods has been developed for part of the Sinai Peninsula of Egypt, a hyperarid area confronted with limited availability of field data, limited understanding of the response of the valley (wadi) to rainfall, and a lack of correspondence between rainfall data and observed flash flood events [2]. 
Sinai Peninsula contains many complex terrains; so rainfall forecasting for complex terrains is challenging and requires numerical simulations at very high resolution.

In arid areas such as Sinai in Egypt, rainfall is mainly caused by squall line and convective cloud mechanisms and by low-intensity frontal rain, causing storm floods [3]. The complexity of terrain influences the weather in a variety of ways. Under stable atmospheric conditions, the terrain generates internal gravity waves that distribute momentum over wider areas. These processes may be related to strong winds and turbulence that influence the air traffic. Under unstable conditions, convective clouds and precipitation are generated over complex terrain which can grow into severe thunderstorms. All the mentioned processes occur on spatial length scales smaller than $100 \mathrm{~km}$, usually even smaller than $10 \mathrm{~km}$.

Because of the above-mentioned challenges, the mesoscale meteorological model named the Advanced Research Weather Research and Forecasting (WRF-ARW) is selected for rainfall forecasting in this research. WRF is developed mainly by the US National Centre for Atmospheric Research (NCAR) in collaboration with many other research centres and universities. WRF allows forecasting weather in complex terrains such as the one in Sinai and in the same time is considering orographic features. It is suitable for a broad spectrum of applications across scales ranging from meters to thousands of kilometres. follows:

The main objectives of this study can be summarized as

(a) the understanding of the processes leading to the flood event at Sinai using WRF?

(b) the investigation of the capability of WRF to simulate successfully the rainfall amount during a flood event?

\section{Study Area}

The Sinai Peninsula (Figure 1), study area, is located in the far northeast of Egypt. It represents about 6\% of Egypt's area which is about $61,000 \mathrm{~km}^{2}$.

The Sinai Peninsula comprises a wedge-shaped block of territory with its base along the Mediterranean Sea coast to the north and its apex bounded by the Gulfs of Suez to the west and Aqaba to the east.

Its southern portion consists of rugged, sharply serrated mountains. These reach elevations of more than 2,400 meters; among them is Mount Catherine, Egypt's highest mountain, which has an elevation of 2,642 meters. The central area of Sinai consists of two plateaus, Al-Tih and Al-Ajmah, both deeply indented and dipping northward toward Wadi (Valley) El Arish.

Toward the Mediterranean Sea, the northward plateau slope is broken by dome-shaped hills; between them and the coast are long, parallel lines of dunes, some of which are more than 100 meters high.

It is dissected by the largest wadi in Sinai, Wadi El Arish, which emerges from elevated gravelly plains and terraces in the south to a distance of about $20 \mathrm{~km}$ till the coast Mediterranean Sea to the north. The rainfall and floods

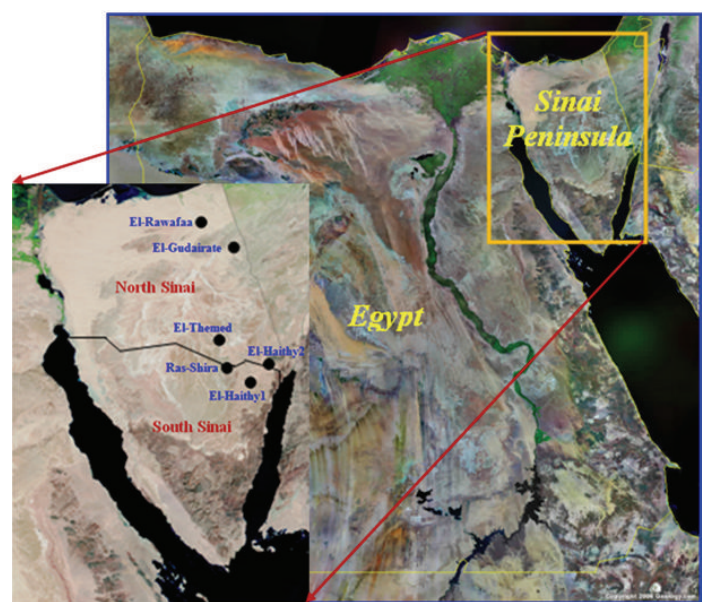

FIGURE 1: Study area and rain gauges location.

are the only sources of renewable water resources in Sinai Peninsula.

2.1. Climate of Sinai Peninsula. It is characterized by the Mediterranean climate in the northernmost of Sinai to be close to the desert and semidesert climate to the south.

Much of the Sinai is hot, or very hot with a higher temperature inland, but there is a more temperate region near the north coast and over the mountains. During the period May/June to September/October, the mean daily maximum is $28^{\circ} \mathrm{C}$ to $37^{\circ} \mathrm{C}$ in the North, $31^{\circ} \mathrm{C}$ to $42^{\circ} \mathrm{C}$ near the south coast, and $35^{\circ} \mathrm{C}$ to $41^{\circ} \mathrm{C}$ inland. Minimum temperatures average between $20^{\circ} \mathrm{C}$ and $25^{\circ} \mathrm{C}$ in the summer.

The winter season is a little less harsh with day high's in the mid-teens and possible 20's, and evenings often falling to around $6^{\circ} \mathrm{C}-10^{\circ} \mathrm{C}$, and may drop below $0^{\circ} \mathrm{C}$.

The amount of rainfall in Sinai decreases from the northeast towards the southwest. The greatest amount of the annual rainfall was found at Rafah station $(304 \mathrm{~mm})$ in the northeast. The annual rainfall average is about $120 \mathrm{~mm}$ along the Mediterranean coast. It decreases in the uplands to the south to about $32 \mathrm{~mm}$. The annual average of rainfall all over Sinai is about 40 millimeters, 27 millimeters from it is estimated to come from one storm that may provide 10 millimeters at a time.

Along the Mediterranean Coast, $60 \%$ of the rain occurs in the winter, while $40 \%$ falls during the transitional seasons.

The annual rainfall in the southern region is significantly less than the northern one, where it reaches $20 \mathrm{~mm}$ in the coastal areas over the Gulfs of Aqaba and Suez. Its amount increases to 70 millimeters over the mountain regions.

The rainfall in autumn and winter seasons is ranging from medium to heavy especially at some high terrain areas. The rainfall is completely nonsexist in summer season.

\section{Data and Methodology}

WRF model is used in this research with its nesting capability to simulate the heavy rainfall with fine grid spacing. 
During the storm mesoscale, convective systems are highly interacted with synoptic-scale environment.

During this study we conducted multinested experiment for four domains with different horizontal resolutions of $81 \mathrm{~km}$ (DM1), $27 \mathrm{~km}$ (DM2), $9 \mathrm{~km}$ (DM3), and $3 \mathrm{~km}$ (DM4), respectively, as shown in Figure 2. The second domain (DM2) will be used to simulate the synoptic situation over Egypt on 18 January, 2010, while the last domain (DM4) will be used to investigate the ability of the WRF model to simulate and predict rainfall to compare it with rain gauges at Sinai.

The model output is adopted to produce its output every hour to be compatible with the rain gauges observations and two-way nesting domain starting from 17 to 19 January, 2010. The 27 vertical layers with the model top of $50 \mathrm{hPa}$ are used in this study.

The initial and lateral boundary meteorological data which used to run the model has been downloaded from the National Centers for Environmental Prediction (NCEP), global final analyses on $1^{\circ} \times 1^{\circ}$ degree from Global Forecasting System (GFS), and it is updated every six hours.

The hourly rainfall data, measured in millimeter $(\mathrm{mm})$, was obtained from the rain gauges stations installed by the Water Resources Research Institute (WRRI); WRRI is the Egyptian governmental research institute with the mandate for flash flood management.

WRF offers multiple physics options that can be combined in any way. The options typically range from simple and efficient to sophisticated and more computationally costly and from newly developed schemes to well-tried schemes such as those in current operational models. Table 1 represents the selected physics of WRF model.

\section{Results and Discussions}

Egypt is subjected to thunderstorms and heavy rains started at the north coast, the Red Sea, and the Sinai Peninsula during 18 January, 2010. This extreme weather and intensive rainfall led to flash flood events over Sinai Peninsula.

The development of intensive weather events that invade Egypt during January 18, 2010, were characterized by "exceptional and extremely heavy rainfall," which affected a wide part of Egypt, including Sinai Peninsula and fatal to some Bedouin tribes located in its path. This heavy rainfall is accompanied by strong winds and thunderstorms.

The Mediterranean region is considered to be one of the most cyclogenetic areas in the world, usually favoring the development of weak low-pressure systems. Occasionally, these systems develop into deep cyclogenesis that cause a series of severe weather events as they cross the Mediterranean.

Generally, the winter season in Middle East is known to be associated with the development of low-pressure systems (Cyprus lows) over the eastern Mediterranean Sea [4]. Such systems have been observed at upper levels, particularly at $500 \mathrm{hPa}$. Rainfall has been observed to be heavy over Sinai and extended to southern parts of Egypt during our case study in winter season, January 18, 2010.

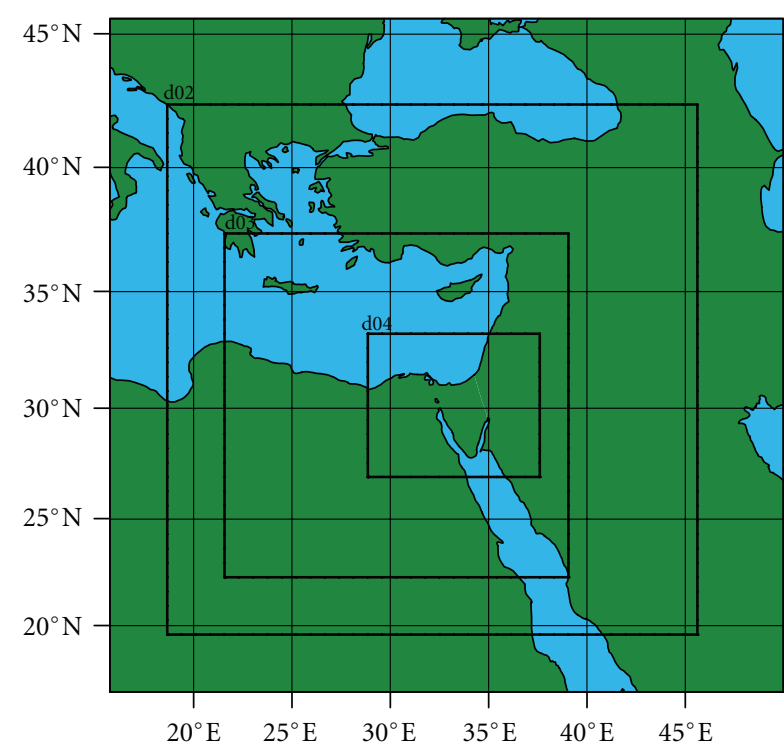

Figure 2: Model domains of $81 \mathrm{~km}, 27 \mathrm{~km}, 9 \mathrm{~km}$, and $3 \mathrm{~km}$ horizontal resolution.

TABLE 1: Selected physics of the WRF model options.

\begin{tabular}{ll}
\hline Physics scheme & $\begin{array}{l}\text { Type of the scheme that used in } \\
\text { WRF run }\end{array}$ \\
\hline Microphysics & $\begin{array}{l}\text { Single-moment 3-class WSM3 } \\
\text { scheme } \\
\text { Rapid Radiative Transfer Model } \\
\text { (RRTM) scheme }\end{array}$ \\
$\begin{array}{l}\text { Longwave radiation } \\
\text { Shortwave radiation }\end{array}$ & $\begin{array}{l}\text { Dudhia scheme } \\
\text { Land surface } \\
\begin{array}{l}\text { Surface and boundary } \\
\text { layers } \\
\text { Cumulus parameterization }\end{array}\end{array}$ \\
\hline
\end{tabular}

Kahana et al. [5] found that Mediterranean Sea cyclones deepen in general, in association with upper level troughs. Upper level troughs are regarded as the key factors in activity of midlatitudes, such as the Mediterranean Sea system, particularly in their front sides, where positive vorticity advection and enhanced convection take place [6]. Ferraris et al. [7], however, found that the polar continental air from central Asia moving toward the eastern Mediterranean, and interacting with the relatively warm sea surface temperature (SST), produces enhanced lower level instability.

Because of the importance of the Mediterranean cyclogenesis, many studies on weather systems in the region have been conducted. The synoptic situation started by the development of the subtropical jet stream in the upper troposphere. The maximum wind speed ranged between 120 and 135 knots as shown in Figure 3, with the southern extension of the polar jet to the south of the Mediterranean.

Figure 3 shows the wind speed of the subtropical branch of the jet stream at $200 \mathrm{hPa}$ for 4 consecutive times per day for our case study, with the southern extension of the polar jet to the east of the Mediterranean Sea. 


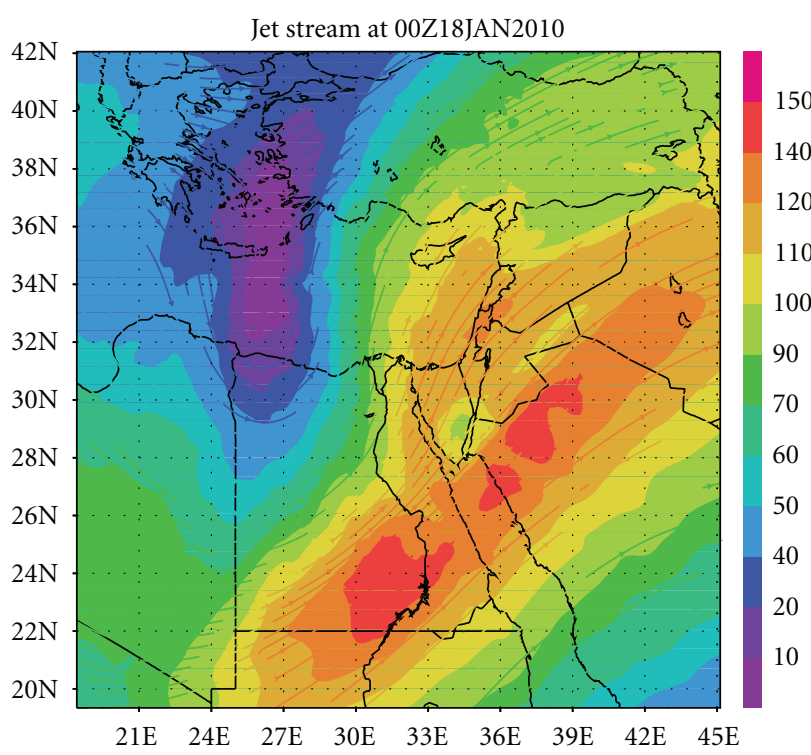

(a)

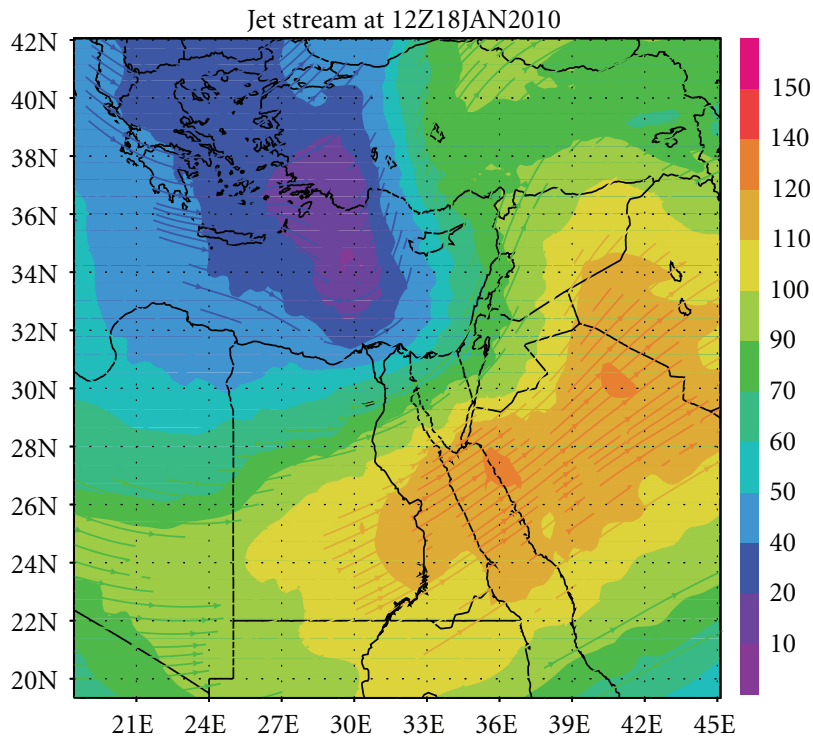

(c)

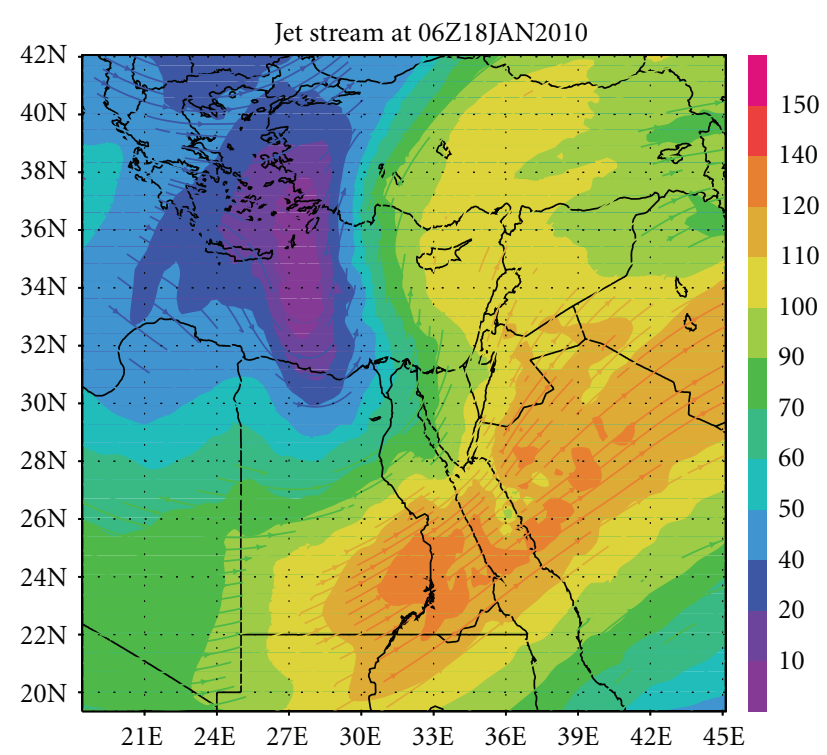

(b)

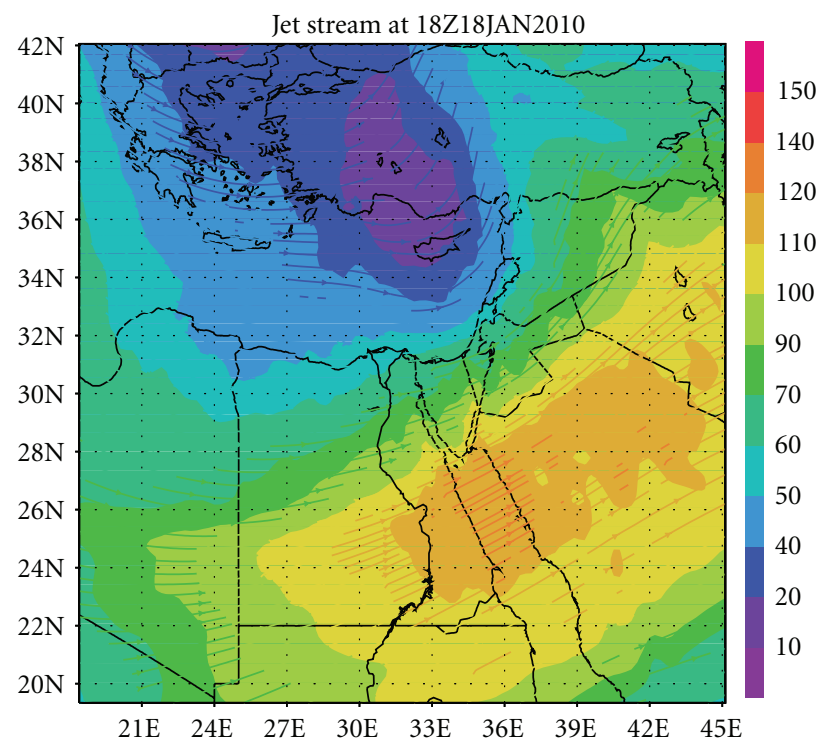

(d)

FIGURE 3: $200 \mathrm{hPa}$ subtropical Jet stream (knots) at over northeastern Africa with the southern extension of the polar jet to the east of the Mediterranean at January 18, 2010.

The synoptic situation can also be analyzed by referring to the midtroposphere. Figure 4 shows the geopotential height at $500 \mathrm{hPa}$ level for the same day; the synoptic system at $500 \mathrm{hPa}$ level also follows the subtropical jet development.

The axis of the trough which is located over east Europe shifts southeast. This trough line orientation indicates that the affected area has extended and engulfed the whole eastern Mediterranean area. This development agrees with Krichak et al. $[8,9]$ and Krichak and Alpert [10] who showed that the meridional orientation of the upper trough line represents the major synoptic process of the development of the East Mediterranean cyclone. As the subtropical jet stream shifts south and splits, the system with high geopotential heights moves eastward and allows the development of a low system in the eastern Mediterranean.

The relative vorticity advection is considered as one of the most important parameter that leads to occurrence of heavy rainfall and flash flood events in Sinai Peninsula. As shown in Figure 5, the positive relative vorticity advections leads to move the upper atmospheric trough from west to east (steering of trough) and reached to Sinai Peninsula.

From Figure 6, we can also follow the temperature advection that calculated using centered finite difference scheme of second order. In the stage of rapid development, there is a cooperative interaction between the upper level and surface flows; strong cold advection is seen to occur west of 


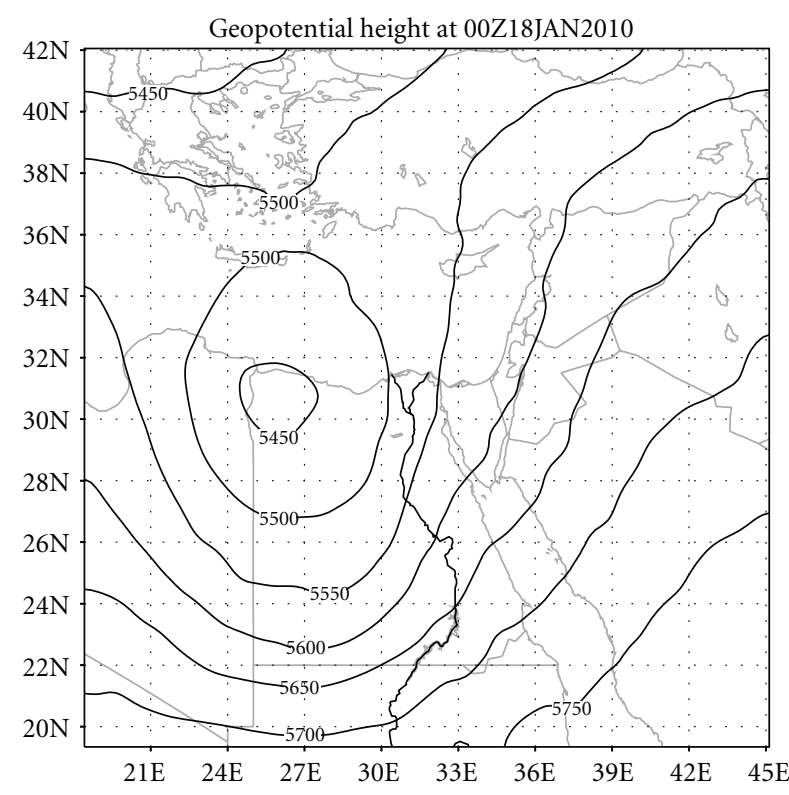

(a)

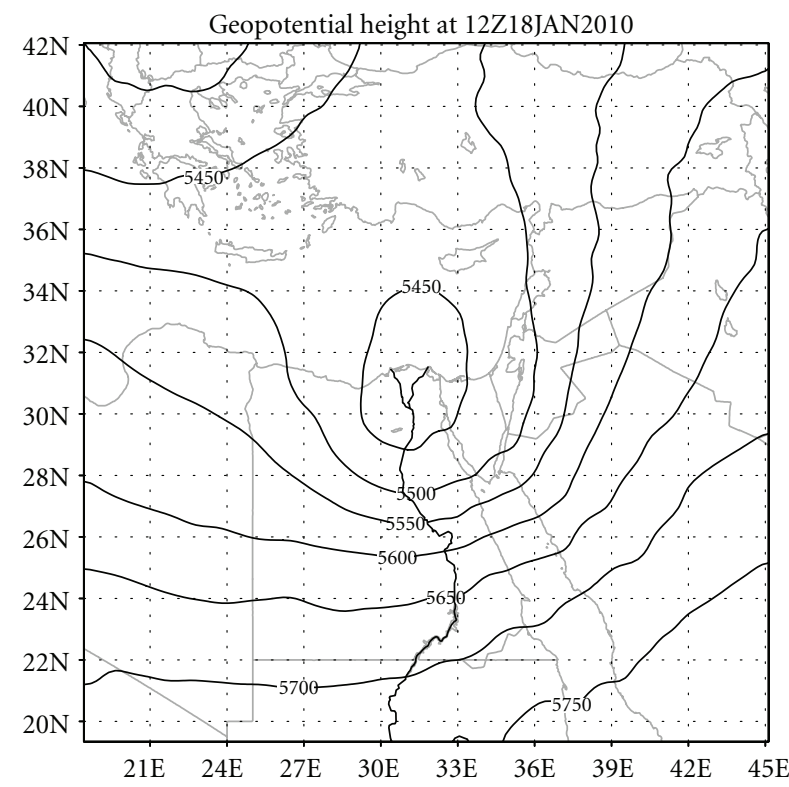

(c)

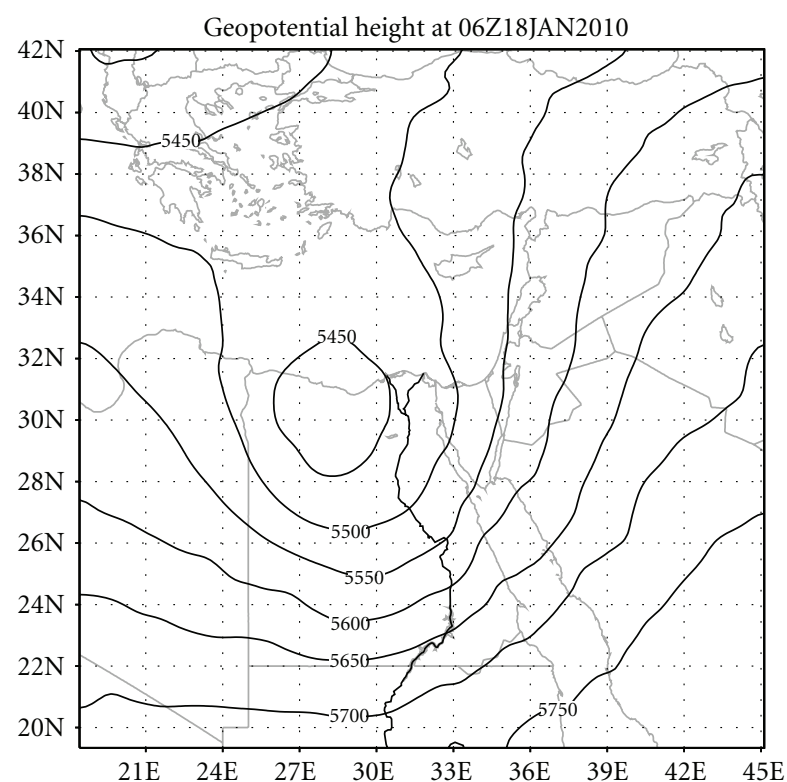

(b)

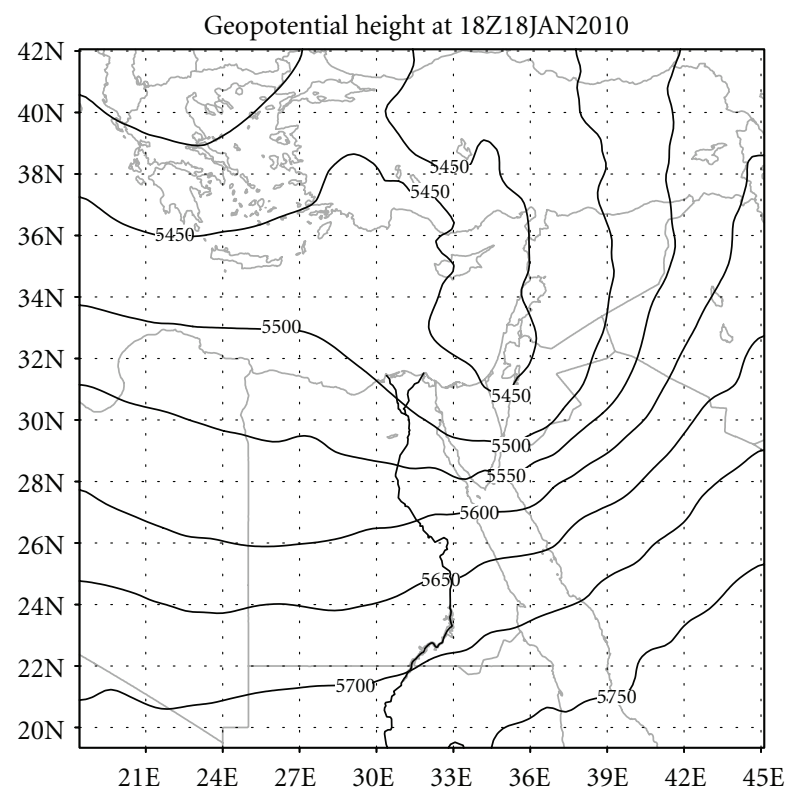

(d)

FIGURE 4: Geopotential height (m), at $500 \mathrm{hPa}$ level every six hours at January 18, 2010.

the trough at the surface, with warm advection to the east. This pattern of thermal advection is a direct consequence of the fact that the trough at $500 \mathrm{hPa}$ lags (lies to the west of) the surface trough. These are consistent with the results of Charney [11], Holton [6, 12], and Bluestein [13], where the growth of midlatitude cyclone is associated with a meridional gradient of temperature. We can expect that the cold advection on the west of the trough is responsible for the decreasing of temperature over Egypt in that period.

The mean sea level pressure (MSLP) of the case study is shown in Figure 7 and follows the system development at the $850 \mathrm{hPa}$ level as shown by the heat advection (Figure 6). The intensification of Azores high, to the west of the region, leads the low system to be developed in the eastern of the Mediterranean region. In addition, this produces a larger air mass temperature difference between the east and west of the low trough line and allows the Red Sea trough to extend northward. The Red Sea trough extension and the meridional orientation of the upper trough permit favorable conditions for the formation and development of the eastern Mediterranean cyclone.

Figure 8 shows the total precipitation associated with the east Mediterranean storm. The rainfall amount increases as 


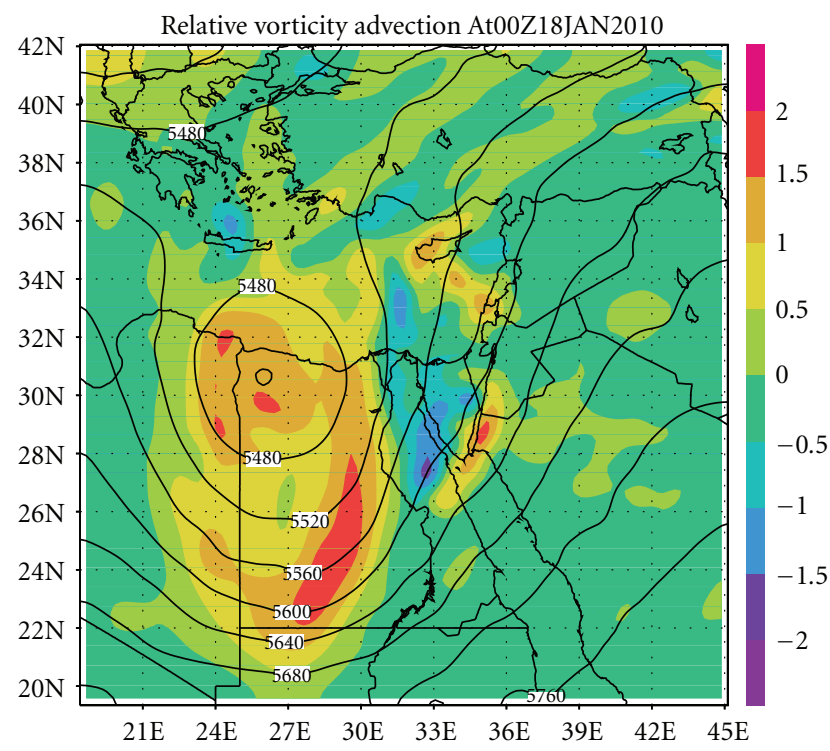

(a)

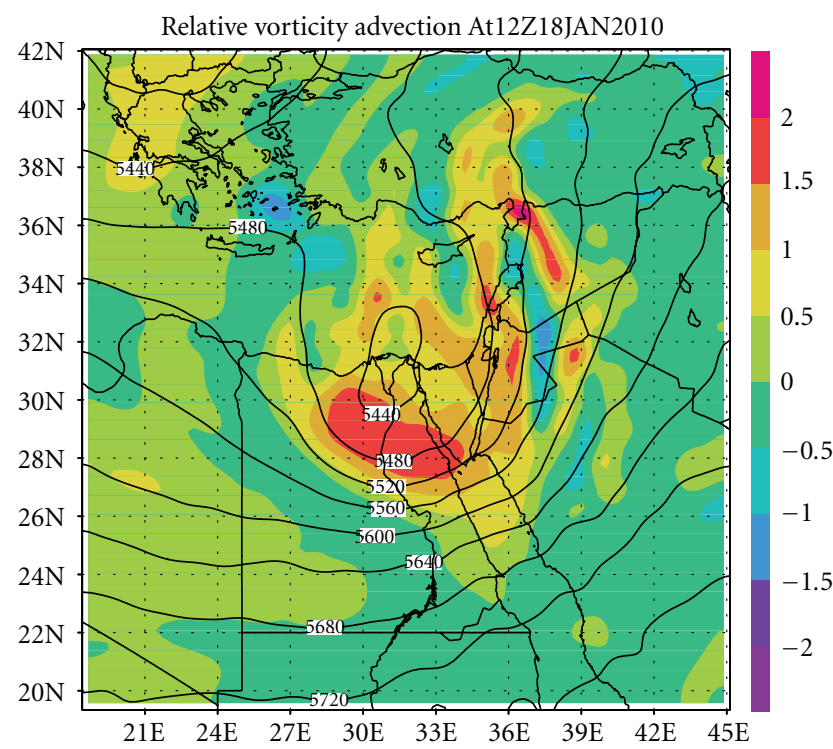

(c)

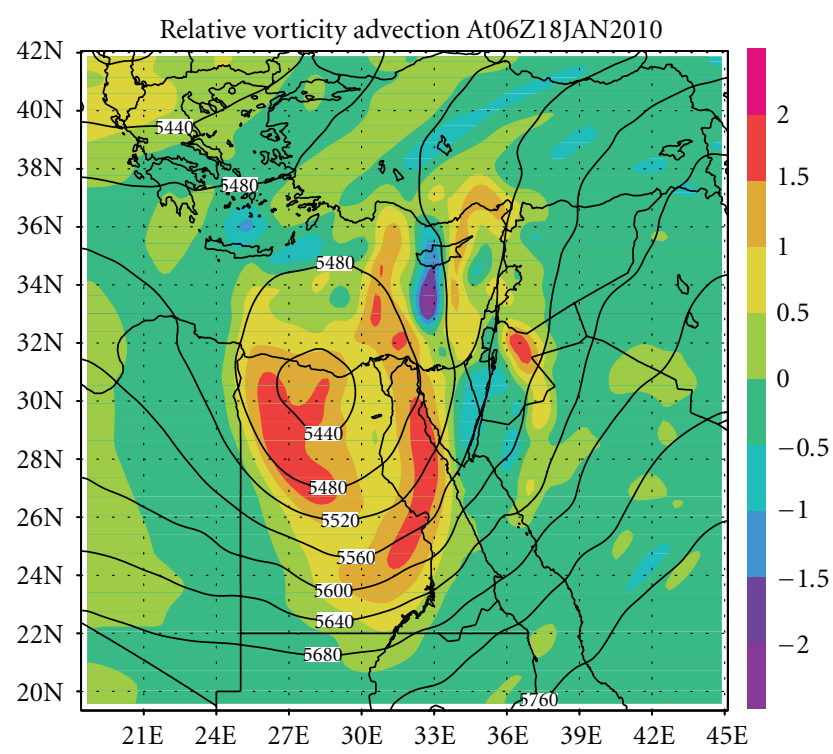

(b)

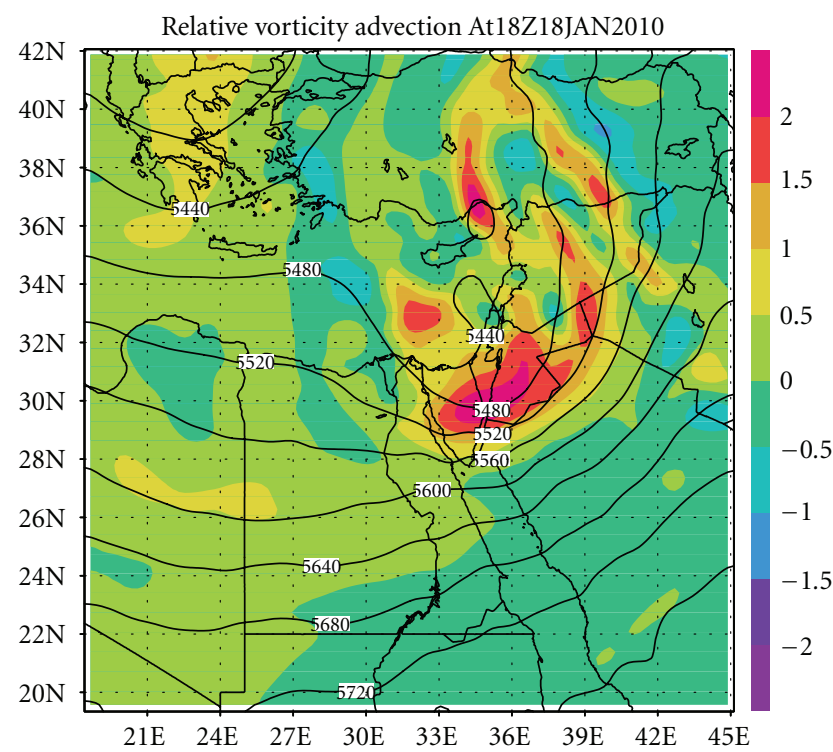

(d)

FIGURE 5: Relative vorticity advections $\left(10^{--5} \mathrm{~S}^{-1}\right)$ with geopotential height contour at $500 \mathrm{hPa}$ level every six hours at January $18,2010$.

the low-pressure system deepens and the precipitation area extends eastward following the surface low.

Evaluation of the performance of WRF model for prediction of heavy rainfall events over Sinai Peninsula will be done by comparison of the rainfall predicted by the WRF model and the rain gauges measurements; the complete information of the rain gauges is shown in Table 2 .

One of the very important statistical tools is the root mean square error (RMSE) which gives a good overall measure of model performance. The weighting of (predictionobservation) by its square tends to inflate RMSE, particularly when extreme values are present. With respect to a perfect model, the root mean square error should approach zero.
TABLE 2: Rain gauges name and location which used in the comparison.

\begin{tabular}{|c|c|c|c|}
\hline No. & Station name & Lon. & Lat. \\
\hline 1 & El-Rawafaa & $34^{\circ} 08^{\prime} 51^{\prime \prime}$ & $30^{\circ} 49^{\prime} 37^{\prime \prime}$ \\
\hline 2 & El-Gudairate & $34^{\circ} 24^{\prime} 35^{\prime \prime}$ & $30^{\circ} 38^{\prime} \quad 28^{\prime \prime}$ \\
\hline 3 & El-Themed & $34^{\circ} 18^{\prime} 19^{\prime \prime}$ & $29^{\circ} 40^{\prime} 37^{\prime}$ \\
\hline 4 & El-Haithyl & $34^{\circ} 36^{\prime} 36^{\prime \prime}$ & $29^{\circ} 29^{\prime} 11^{\prime \prime}$ \\
\hline 5 & El-Haithy2 & $34^{\circ} \quad 42^{\prime} 24^{\prime \prime}$ & $29^{\circ} 28^{\prime} \quad 04^{\prime \prime}$ \\
\hline 6 & Ras-Shira & $34^{\circ} 27^{\prime} 57^{\prime \prime}$ & $29^{\circ} 31^{\prime} 02^{\prime \prime}$ \\
\hline
\end{tabular}

On the other hand, the mean bias (MB) is considered also to evaluate the model performance which represents the 


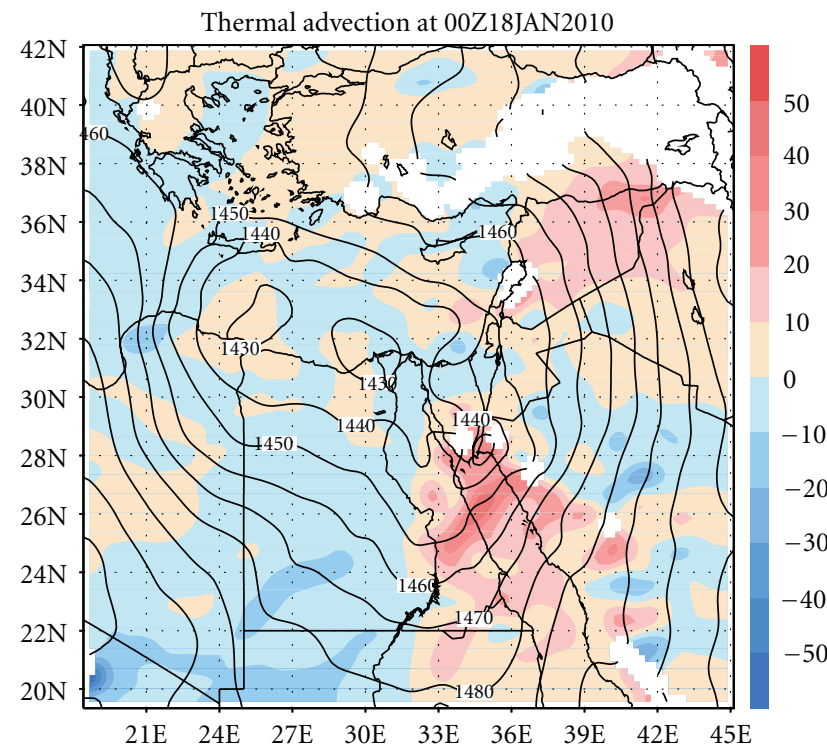

(a)

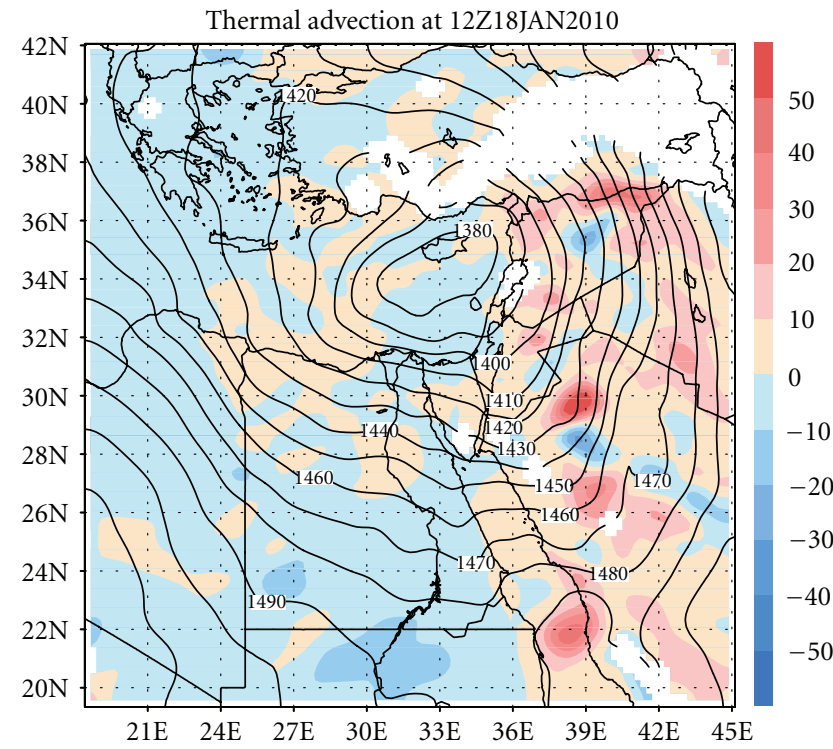

(c)

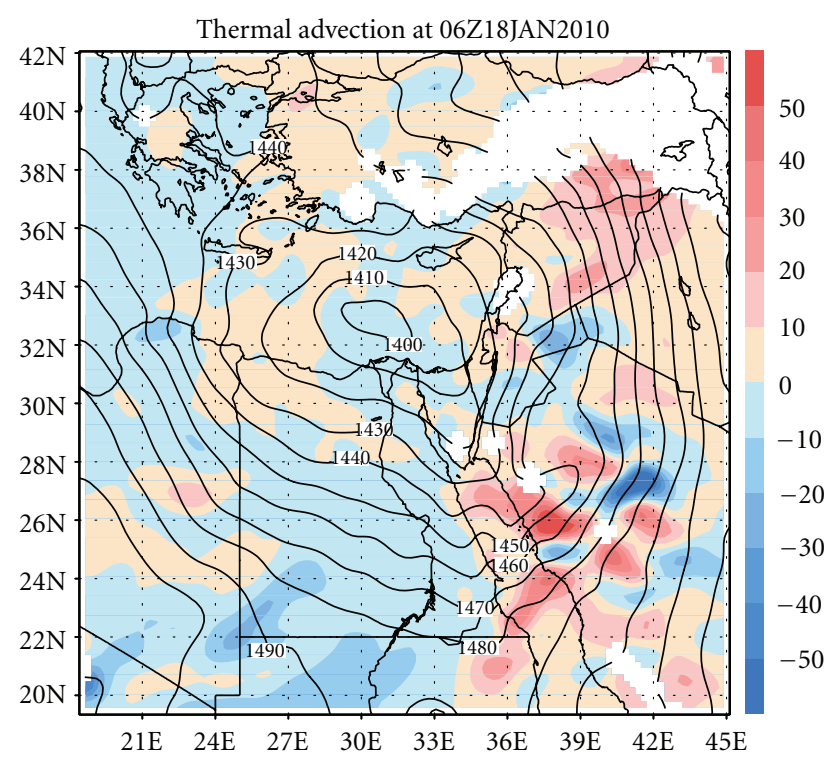

(b)

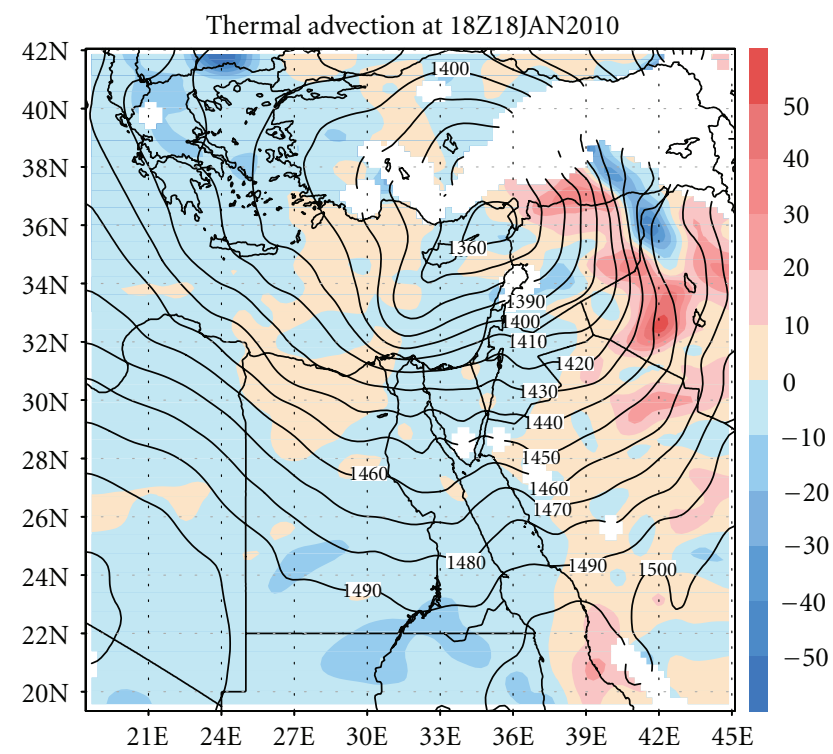

(d)

Figure 6: Thermal advection $\left({ }^{\circ} \mathrm{C}\right)$ with geopotential height contour at $850 \mathrm{hPa}$ level every six hours at January 18, 2010.

degree of correspondence between the mean prediction and the mean observation. Lower numbers are best and values less than 0 indicate underprediction.

The equations for RMSE, MB and its percentages are given as follows:

$$
\begin{gathered}
\operatorname{RMSE}=\left(\sum_{i=1}^{n} \frac{\left(X_{p}-X_{o}\right)^{2}}{n}\right)^{0.5}, \\
\operatorname{RMSE} \%=\left(\frac{\mathrm{RMSE}}{\overline{X_{o}}}\right) * 100,
\end{gathered}
$$

$$
\begin{aligned}
\mathrm{MB} & =\sum_{i=1}^{n} X_{p}-\frac{X_{o}}{n}, \\
\mathrm{MB} \% & =\left(\frac{\mathrm{MB}}{\overline{X_{o}}}\right) * 100,
\end{aligned}
$$

where $n$ is number of observations, $X_{p}$ and $X_{o}$ are the predicted and observed values, respectively, and $\overline{X_{o}}$ is the average of observed values.

These statistical measures are used extensively for evaluation of model forecasts of precipitation (e.g., [14-16]). The 


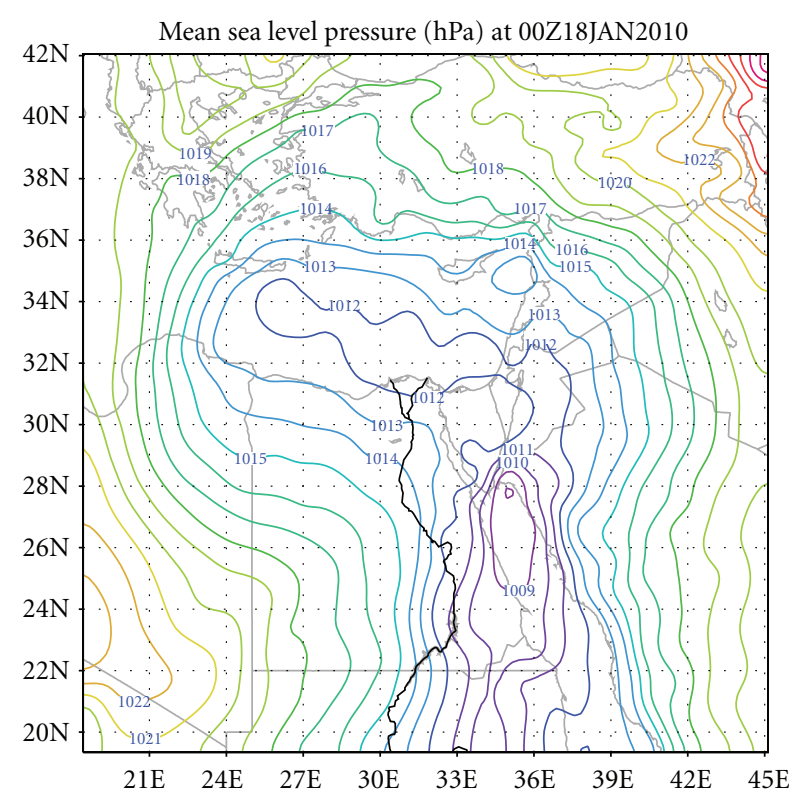

(a)

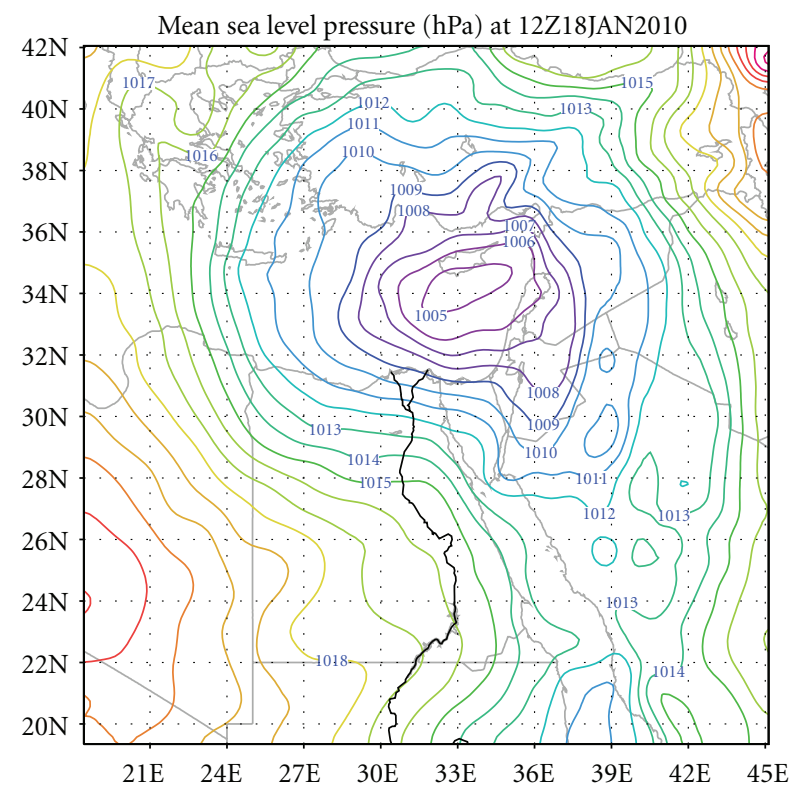

(c)

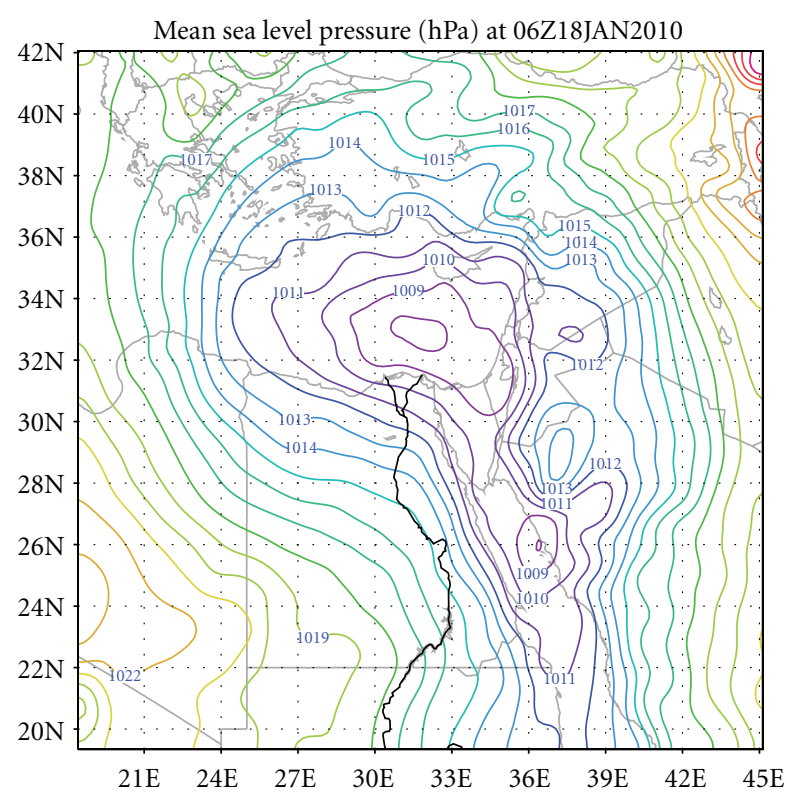

(b)

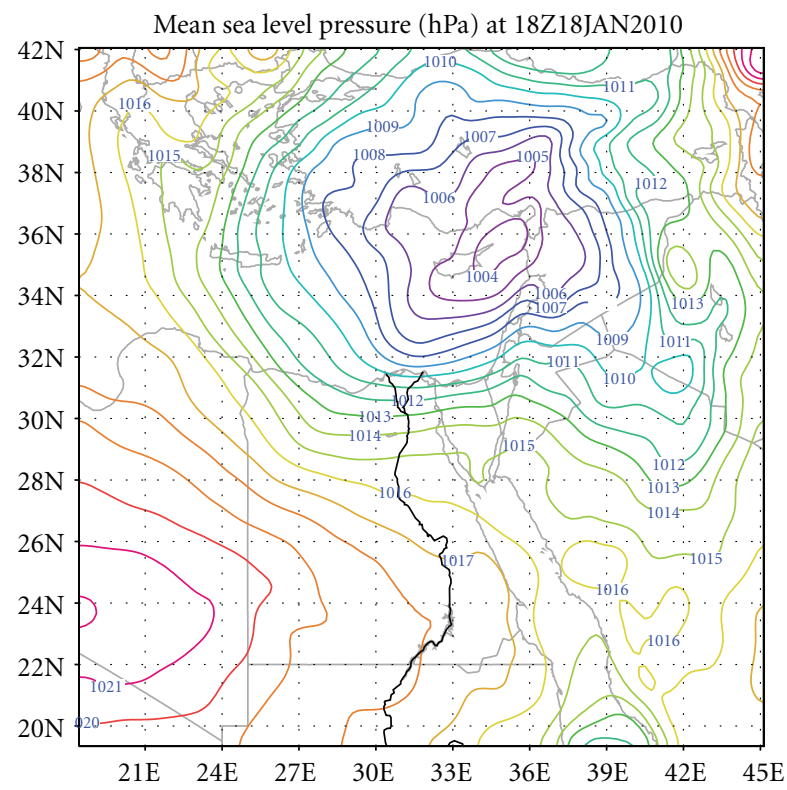

(d)

FIgURE 7: Mean sea level pressure (hPa) every six hours at January 18, 2010.

quantitative validation of the simulated precipitation is done by calculating their differences with the corresponding rain gauges.

Figure 9 shows the comparisons between the predicted hourly rainfall and the measured ones in different regions over Sinai Peninsula during January 18, 2010.

From Figure 9, it can be noticed that the predicted rainfall by WRF model is in a good consistency and harmony with observed rainfall for all rain gauge stations.

In El-Gudairate, El-Rawafaa, El-Haithy2, and El-Themed Stations rainfall prediction by WRF is very close to the measured ones. But in the other stations such as El-Haithyl and Ras-Shira, it gave small differences with the measured rainfall during January 18, 2010.

Table 3 shows the percentages of root mean square error and mean bias for predicted rainfall and the measured ones at different stations.

It can be deduced from this table that the maximum values of root mean square error and mean bias are for ElHaithyl station, while the minimum values of root mean square error and mean bias are for El-Gudairate, El-Rawafaa, El-Haithy2, El-Themed, and Ras-Shira Stations.

This means the WRF model has high-performance rainfall prediction for all stations except El-Haithyl station. 


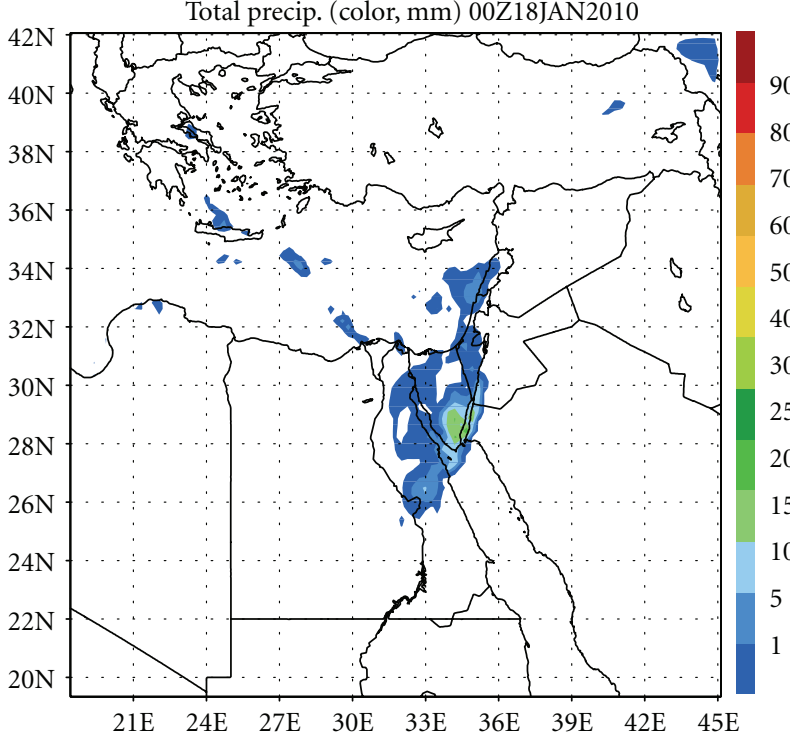

(a)

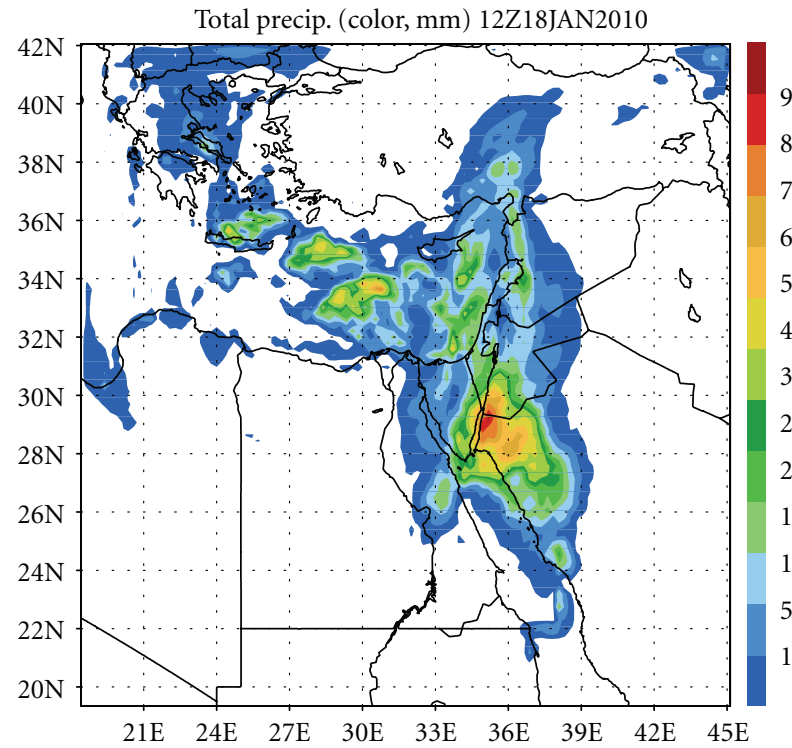

(c)

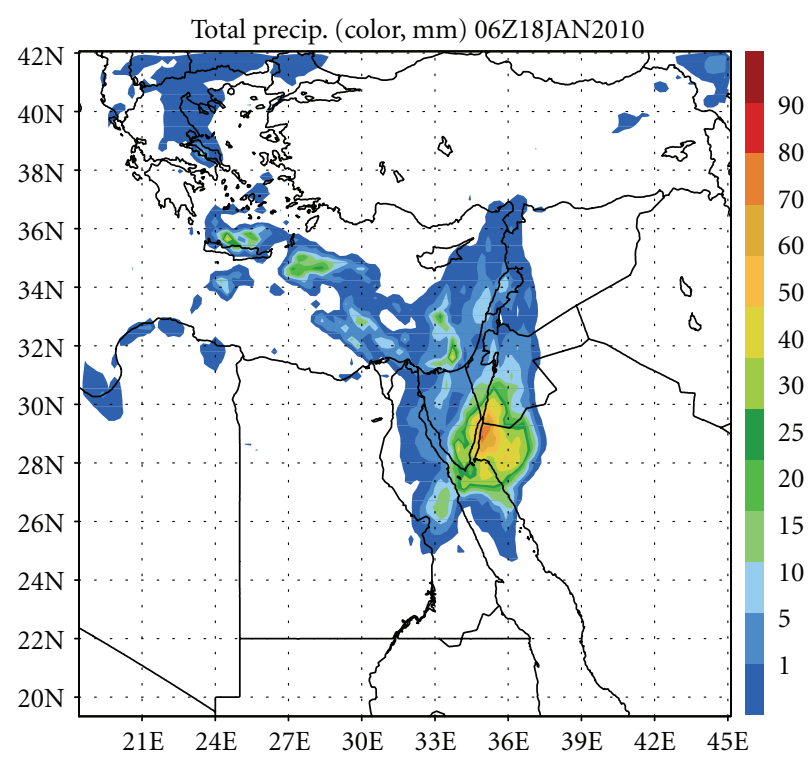

(b)

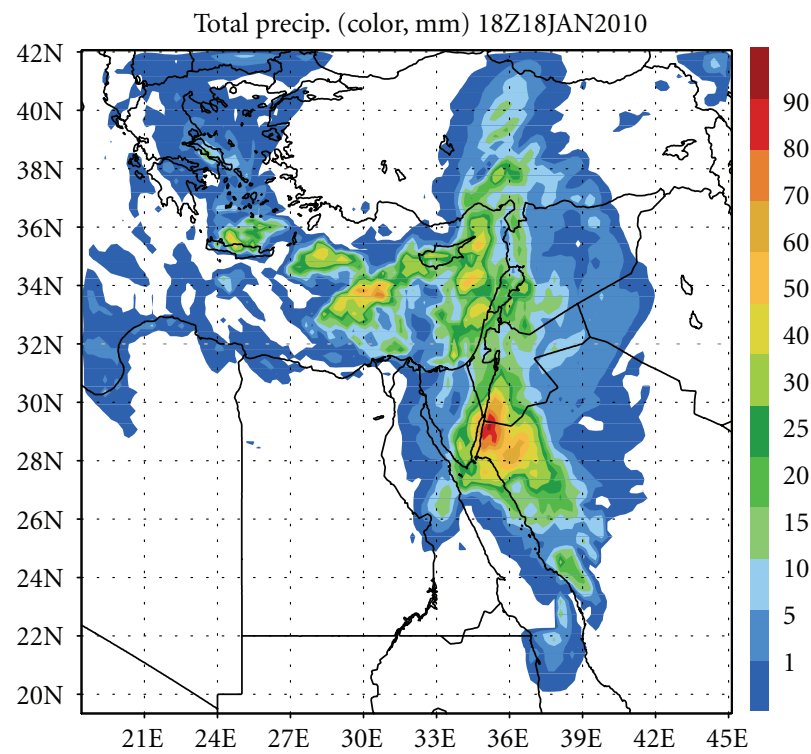

(d)

Figure 8: Accumulated rainfall (mm) during January 18, 2010 plotted every six hours with the maximum volume of rainfall over Sinai Peninsula.

TABLE 3: The percentages of root mean square error and mean bias for rainfall from WRF and the measurements at different stations.

\begin{tabular}{lcc}
\hline Station & RMSE \% & MB \% \\
\hline El-Gudairate & 4.5 & -0.3 \\
El-Rawafaa & 8.6 & 0.7 \\
El-Themed & 11.8 & 1.2 \\
El-Haithyl & 30.7 & 20.4 \\
El-Haithy2 & 4.7 & 1.3 \\
Ras-Shira & 15.8 & -4.2 \\
\hline
\end{tabular}

The WRF model was able to simulate the synoptic situation which invaded Egypt and accompanied by heavy rains started at the north coast, the Red Sea, and the Sinai Peninsula during 18 January, 2010.

In the same time, the model simulation of the synoptic situation was in a good compatibility with the previous studies.

It may conclude that the performance of WRF model approximately gave a good and reasonable rainfall prediction compared to measurements at all stations over Sinai Peninsula. 


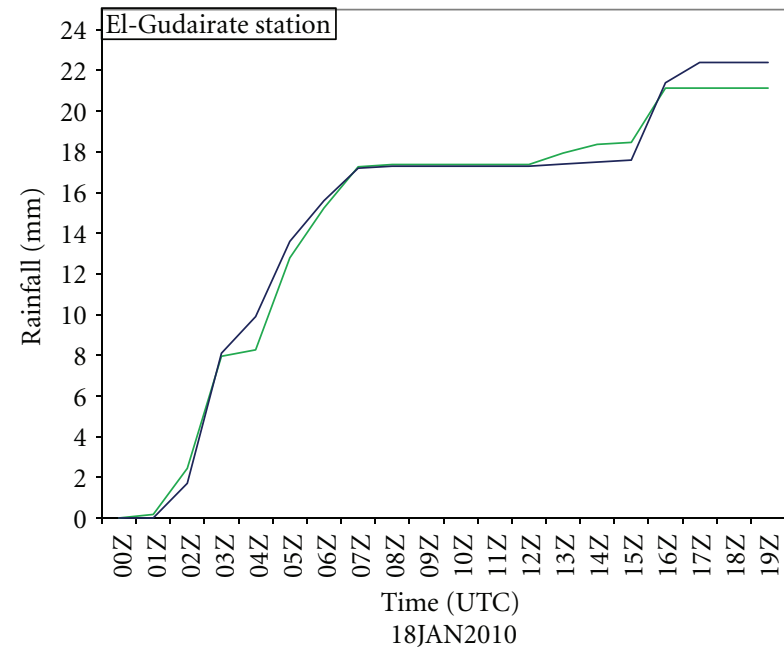

(a)

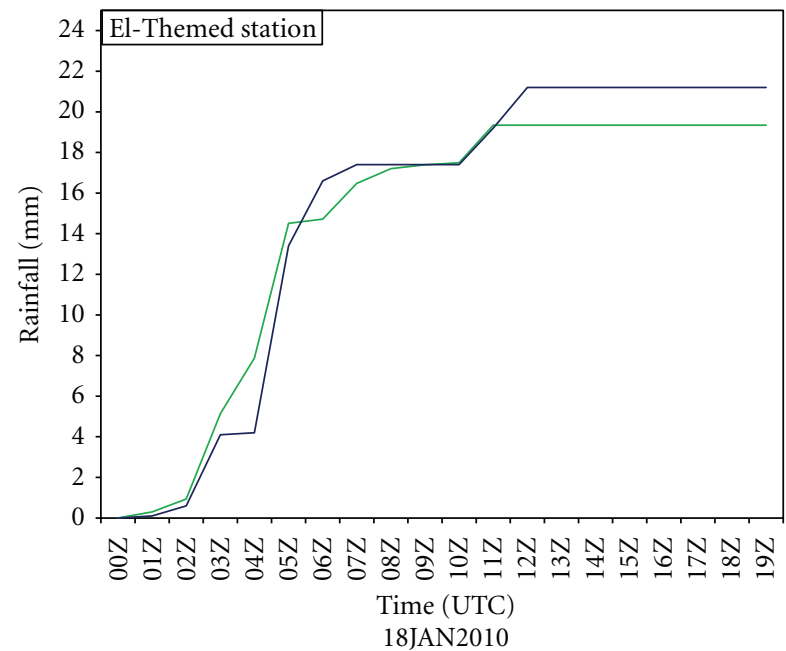

(c)

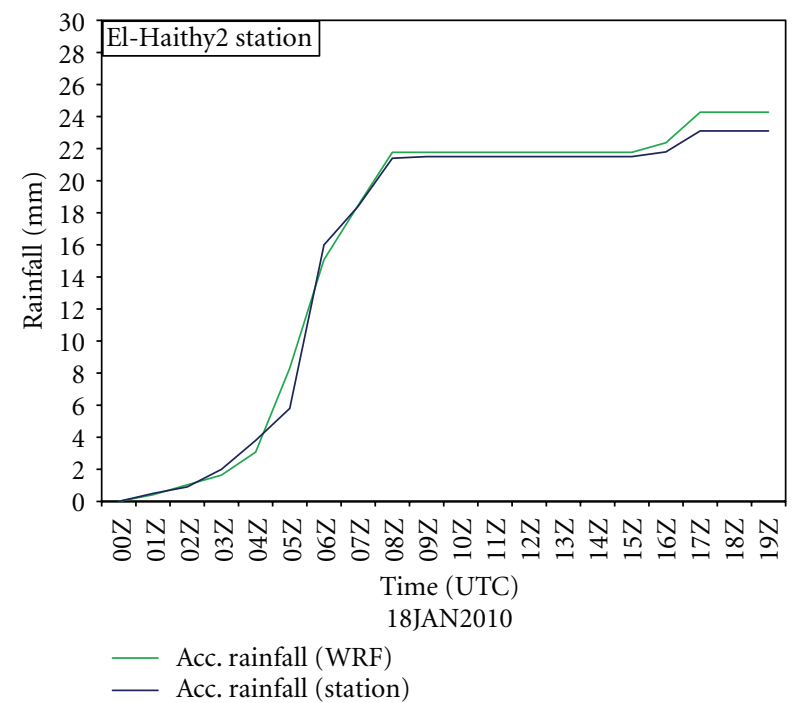

(e)

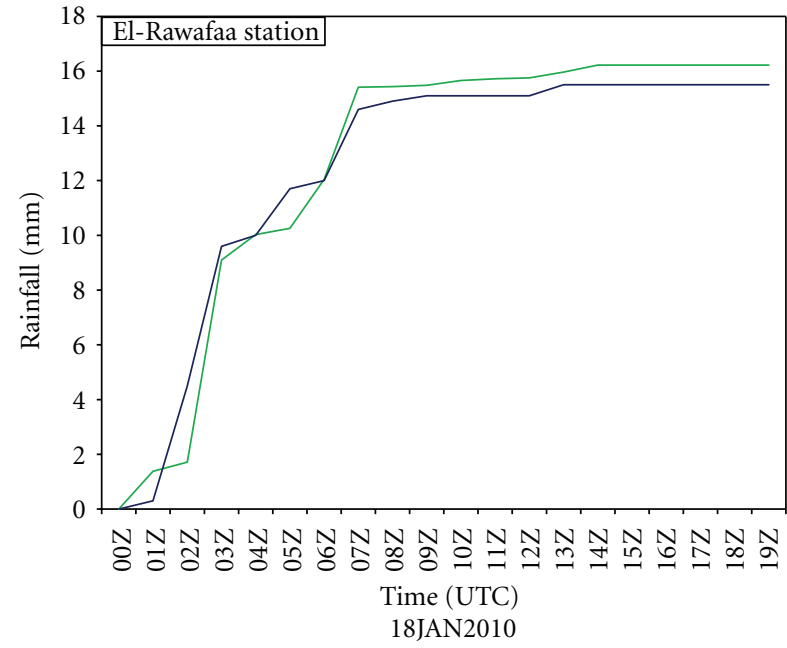

(b)

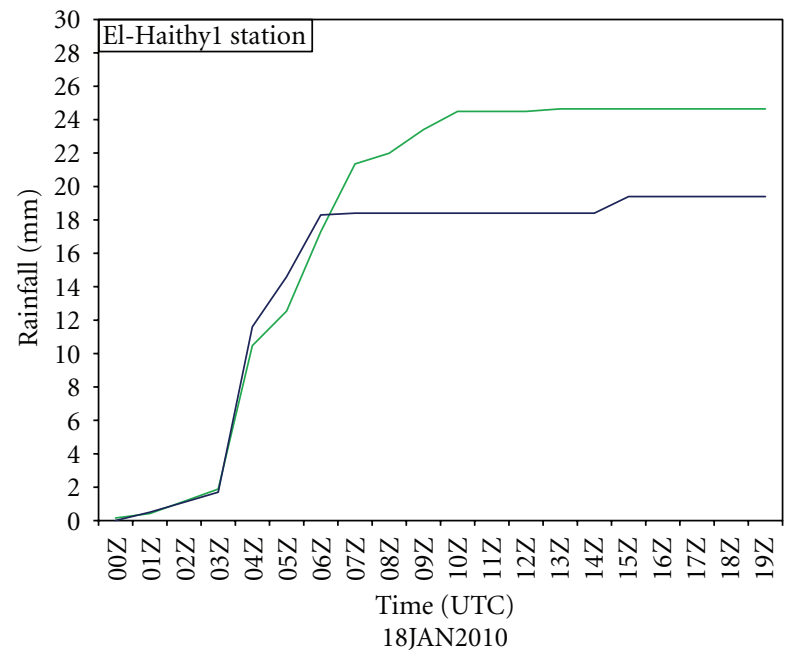

(d)

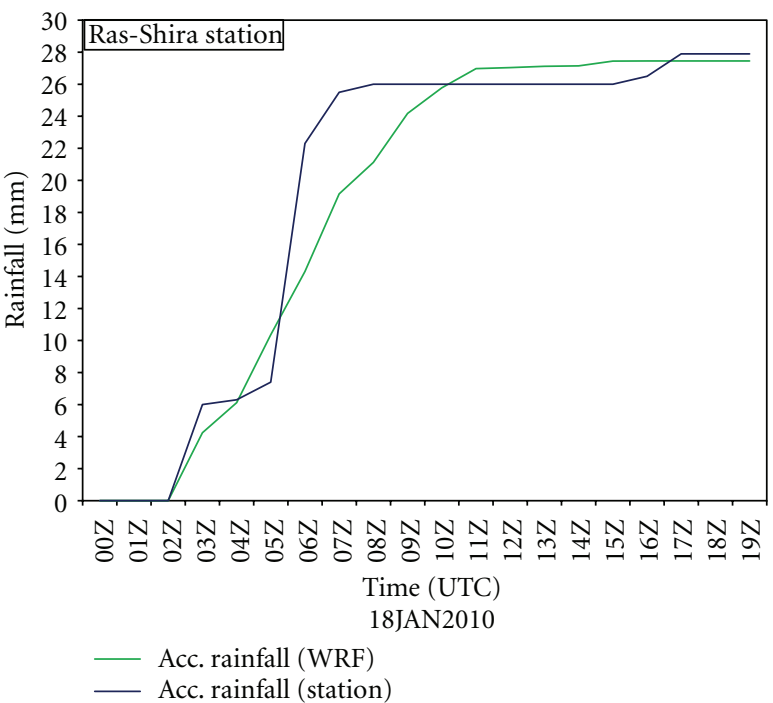

(f)

FIGURE 9: Comparison between accumulated observed and predicted precipitations ( $\mathrm{mm}$ ) for El-Gudairate, El-Rawafaa, El-Themed, ElHaithyl, El-Haithy2, and Ras-Shira stations through January 18, 2010. 


\section{Conclusions}

The WRF model was able to simulate the synoptic situation which invaded Egypt and accompanied by heavy rains started at the north coast, the Red Sea, and the Sinai Peninsula during January 18, 2010.

In the same time, the model simulation of the synoptic situation was in a good compatibility and agreement with the previous studies over the Mediterranean region.

It may be concluded that the performance of WRF model approximately gave a good and reasonable rainfall prediction compared to measurements at all stations over Sinai Peninsula.

\section{References}

[1] D.-K. Lee, H.-R. Kim, and S.-Y. Hong, "Heavy rainfall over Korea during 1980-1990," Korean Journal of the Atmospheric Sciences, vol. 1, no. 1, pp. 32-50, 1998.

[2] J. Cools, P. Vanderkimpen, G. El Afandi et al., "An early warning system for flash floods in hyper-arid Egypt," Natural Hazards and Earth System Sciences, vol. 12, no. 2, pp. 443-457, 2012.

[3] G. El Afandi, "Developing flash-flood guidance in Egypt's Sinai Peninsula with the Weather Research forecast (WRF) model," International Journal of Meteorology, vol. 35, no. 347, pp. 75-82, 2010.

[4] C. A. Babu, A. A. Samah, and H. Varikoden, "Rainfall climatology over Middle East region and its variability," International Journal of Water Resources \& Arid Environments, vol. 1, no. 3, pp. 180-192, 2011.

[5] R. Kahana, B. Ziv, U. Dayan, and Y. Enzel, "Atmospheric predictors for major floods in the Negev Desert, Israel," International Journal of Climatology, vol. 24, no. 9, pp. 1137-1147, 2004.

[6] J. Holton, An Introduction to Dynamic Meteorology, Academic Press, New York, NY, USA, 2nd edition, 1992.

[7] L. Ferraris, R. Rudari, and F. Siccardi, "The uncertainty in the prediction of flash floods in the northern Mediterranean environment," Journal of Hydrometeorology, vol. 3, pp. 714-727, 2002.

[8] S. O. Krichak, P. Alpert, and T. N. Krishnamurti, "Interaction of topography and tropospheric flow-a possible generator for the Red Sea trough?" Meteorology and Atmospheric Physics, vol. 63, no. 3-4, pp. 149-158, 1997.

[9] S. O. Krichak, P. Alpert, and T. N. Krishnamurti, "Red Sea Trough/cyclone development-numerical investigation," Meteorology and Atmospheric Physics, vol. 63, no. 3-4, pp. 159-169, 1997.

[10] S. O. Krichak and P. Alpert, "Role of large scale moist dynamics in November 1-5, 1994, hazardous Mediterranean weather," Journal of Geophysical Research D, vol. 103, no. 16, pp. 1945319468, 1998.

[11] J.G. Charney, "The dynamics of long waves in a baroclinic westerly current," Journal of Atmospheric Sciences, vol. 4, no. 5, pp. 136-162, 1947.

[12] J. Holton, An Introduction to Dynamic Meteorology, Academic Press, New York, NY, USA, 3rd edition, 1992.

[13] H. B. Bluestein, Synoptic-Dynamic Meteorology in Midlatitudes, Vol. II: Observations and Theory of Weather Systems, Oxford University Press, Oxford, UK, 1992.
[14] F. Mesinger, T. L. Black, D. W. Plummer, and J. H. Ward, "Eta model precipitation forecasts for a period including tropical storm Allison, Wea," Forecasting, vol. 5, pp. 483-493, 1990.

[15] F. Mesinger, "Improvements in quantitative precipitation forecasts with the eta regional model at the national centers for environmental prediction: the 48-km upgrade," Bulletin of the American Meteorological Society, vol. 77, no. 11, pp. 2637-2649, 1996.

[16] K. Lagouvardos, V. Kotroni, A. Koussis, C. Feidas, A. Buzzi, and P. Malguzzi, "The meteorological model BOLAM at the National Observatory of Athens: assessment of two-year operational use," Journal of Applied Meteorology, vol. 42, pp. 1667$1678,2003$. 

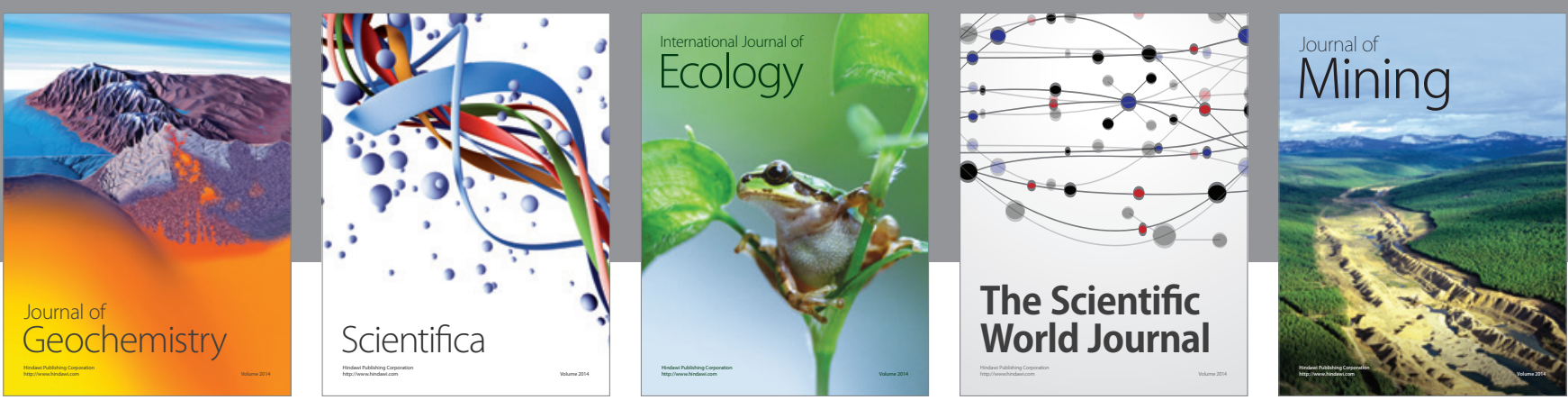

The Scientific World Journal
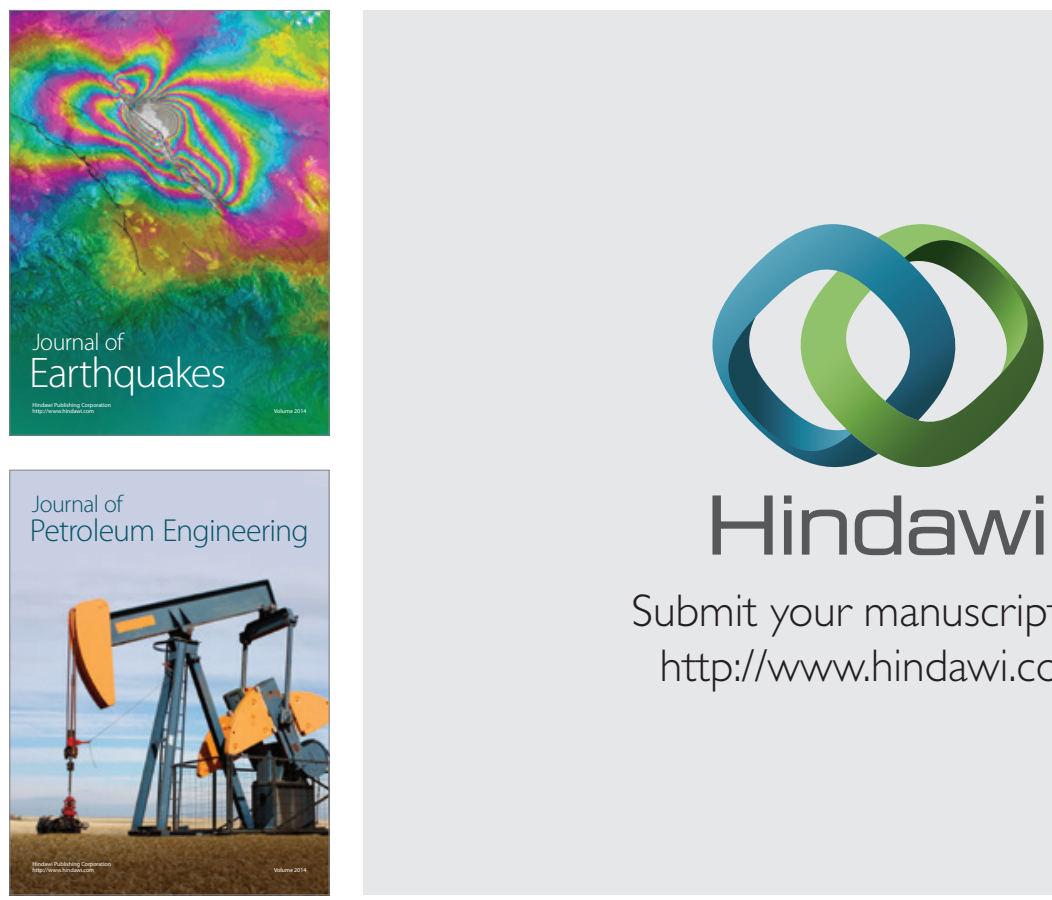

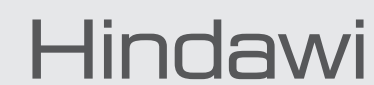

Submit your manuscripts at

http://www.hindawi.com
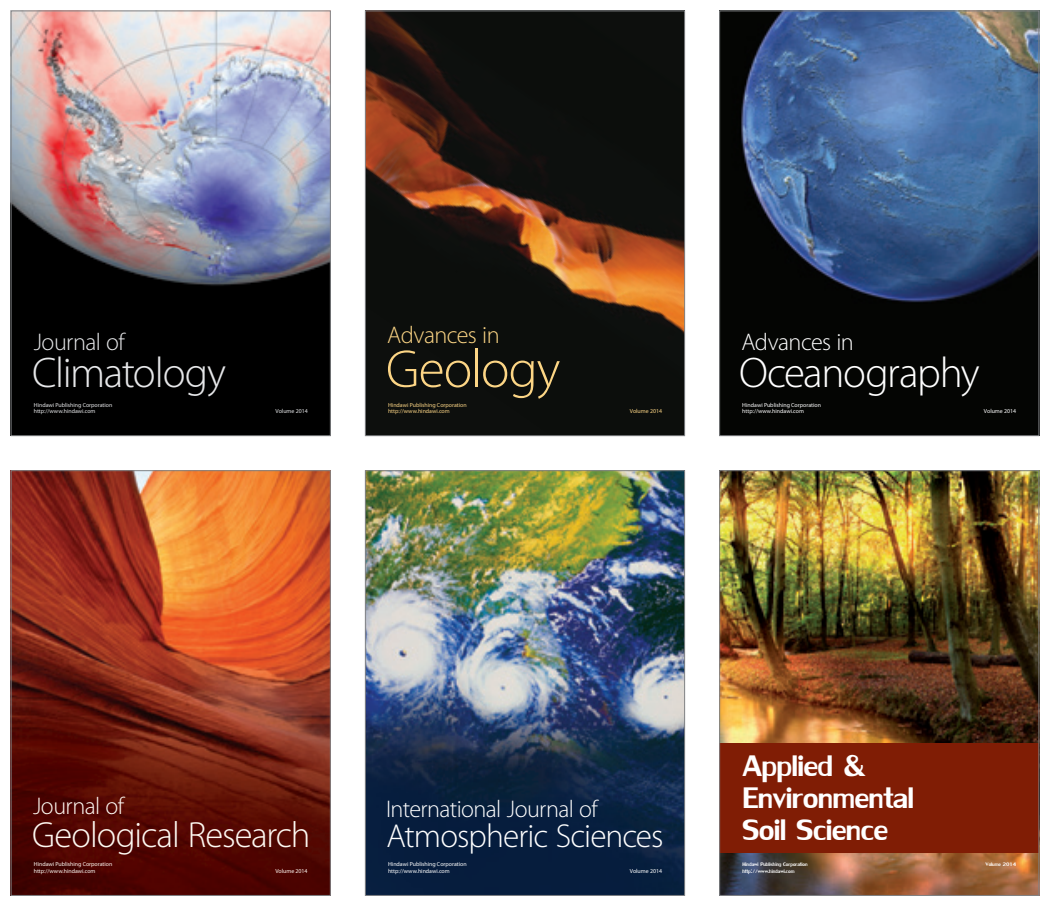
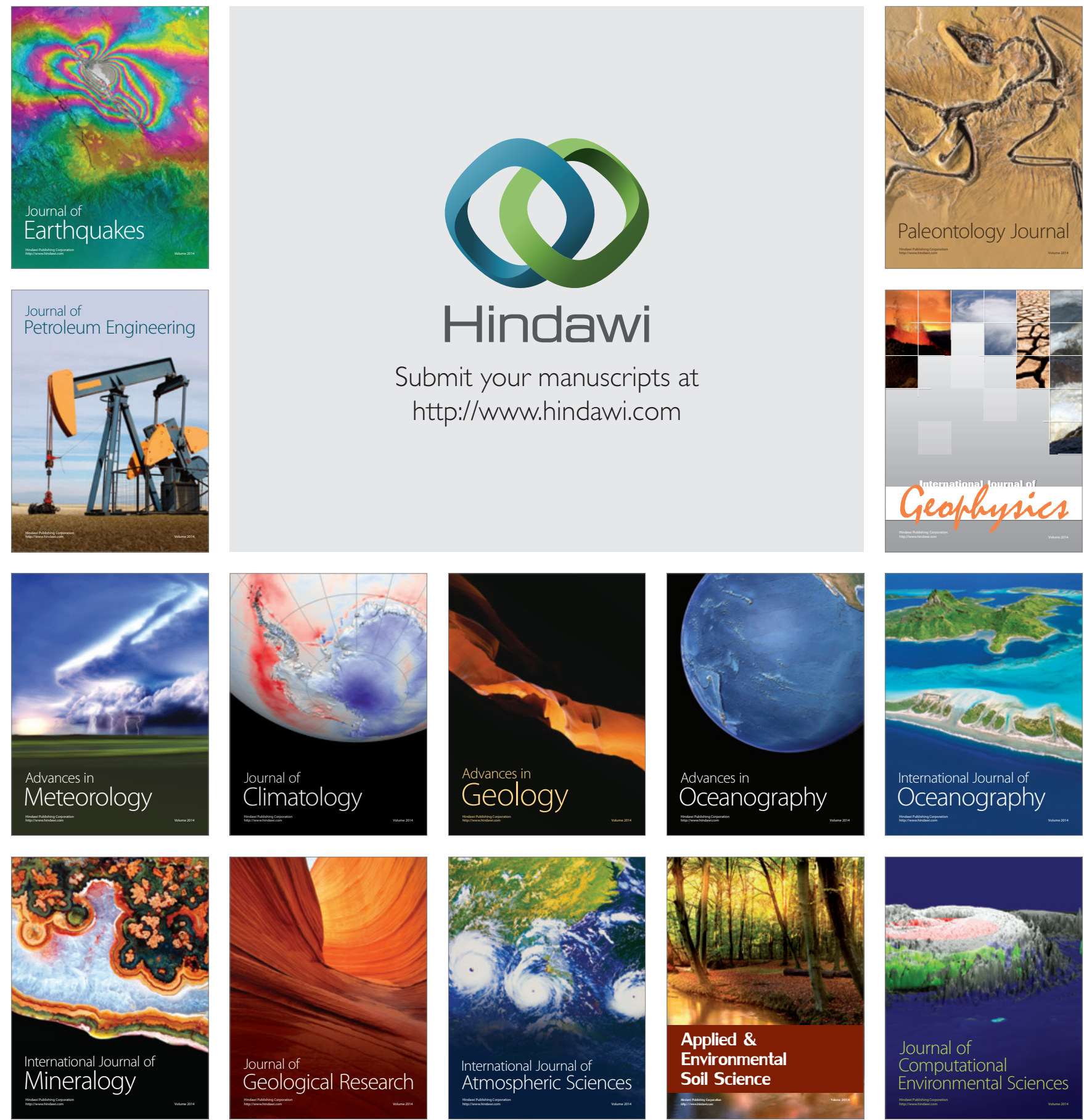